\title{
The influence of treatments upon the nutritive value of sugar cane residues
}

\author{
F Ojeda \\ Estacion Experimental de Pastos y Forrajes "Indio Hatuey", Central "Espana Republicana",
} CP 44280, Matanzas, Cuba

Cuba produces $10^{8}$ ton/year of sugar cane residues i.e. top leaves and straws. However their nutritional values are low. The better possibility to overcome this insufficiency is to treat these residues.

Our study consisted in treating the sugar cane residues with urea-generated ammonia, and adding fresh filter mud and final molasses as supplementary nutrients. Compaction of materials was facilitated by increasing their moisture. Three 500 t capacity stack silos were used to achieve the following 3 treatments. A) long residues $(15-20 \mathrm{~cm})$ plus $10 \mathrm{~kg}$ urea and $80 \mathrm{~kg}$ fresh filter mud per ton residues in altern layers. B) short residues $(2-4 \mathrm{~cm})$ plus $20 \mathrm{~kg}$ urea, $40 \mathrm{~kg}$ final molasses and $10 \mathrm{~kg}$ mineral salts per ton added when filling the silo. C) long residues plus $20 \mathrm{~kg}$ urea and $390 \mathrm{~kg}$ tresh filter mud per ton in altern layers. Silos A and B were covered with $30 \mathrm{~cm}$ of fresh filter mud. Silo $\mathrm{C}$ remained uncovered.

Treatment $C$ showed the worst quality of fermentation and has lower crude protein content $(7.2 \% \mathrm{DM})$ compared to A ( $8.0 \% \mathrm{DM})$ and $B(8.9 \%$ DM). Five sheep (in metabolism crates) per treatment were used to measure intake and digestibility; they were fed ad libitum for 2 week adaptation and one week measurement. Dry matter intake ( $\left.g / W^{0.75}\right)$ was significatively higher $(P<0.05)$ in $A\left(35.3^{a}\right)$ and $C\left(30.5^{b}\right)$ than in $B\left(27.4^{c}\right)$ probably due to a higher possibility of selection by the animals. Organic matter digestibility was higher with $\mathrm{A}$ $(55.8 \%$ ) and $B(55.5 \%$ a) than with $C$ $(46.6 \%$ c). Crude protein digestibility was not significatively different between treatments (mean $=27.3 \%)$ and was very low with respect to crude protein content. This observation is consistent with those made with $\mathrm{NH}_{3}$ treatments and suggest that the $\mathrm{N}$ fixed through treatment is either too much bound with non digestible cell-walls or not fully used by rumen microbes, or both.

In conclusion, it is possible to consider that treatment $A$ is the optimal treatment in terms of nutritive value improvement/cost of treatment ratio. 